\title{
Genotoxicity of Momordica cymbalaria on Bone Marrow Cells of Swiss Albino mice
}

\author{
Melvin Mariyam Varghese ${ }^{1}$, Kusu Susan Cyriac ${ }^{2 *}$, Raju Koneri ${ }^{3}$,Srikanth Darisi ${ }^{4}$, Vinushree B N ${ }^{5}$, Gayathri \\ Suresh KP ${ }^{6}$
}

1 Department of Pharmacology, Karnataka College of Pharmacy, Bangalore.

2 Department of Pharmacology, Karnataka College of Pharmacy, Bangalore. 3 Central Research Laboratory BGS Global Institute of Medical Science, Bangalore.

4 Department of Pharmacy Practice, Karnataka College of Pharmacy, Bangalore.

5 Department of Pharmacy Practice, Karnataka College of Pharmacy, Bangalore.

6 Department of Pharmacy Practice, Karnataka College of Pharmacy, Bangalore.

*Corresponding author: kusususan@gmail.com

\begin{abstract}
Genotoxicity is described as the property of the agent to cause changes in the genetic material leading to damage in the genetic information, such agents are called as genotoxins. This property is much seen in drugs that are used in the treatment of cancer. Cyclophosphamide is an anticancer drug that lead to gene toxicity through formation of its metabolites and generation of reactive oxygen species and free radicals that damage the genetic material. The main objectives of this research is to evaluate the effect of Momordica cymbalaria $(10 \mathrm{mg} / \mathrm{kg}$ and $50 \mathrm{mg} /$ $\mathrm{kg}$ ) on cyclophosphamide induced genotoxicity and also to study the genotoxic effect of Momordica cymbalaria $(50 \mathrm{mg} / \mathrm{kg})$ without Cyclophosphamide treatment. The dose selection was made based on previous acute toxicity report. Animals were treated with Momordica cymbalaria and bone marrow cells were been isolated to observe the effect of drugs on the chromosomes and cellular division through chromosomal aberration assay and micronuclei assay respectively. Effect of drugs on the anti-oxidant enzymes such as glutathione and cellular lipid peroxidation was studied using the liver homogenate. The test drug Momordica cymbalaria showed significant genoprotective effect in dose dependent manner against the chromosomal aberrations and micronuclei formation induced by Cyclophosphamide. And also there was significant inhibition of lipid peroxidation and rise in GSH levels indicating the anti-oxidant property of the test drugs. The drugs Momordica cymbalaria has significant gene protecting effect in cells from Cyclophosphamide induced genotoxicity
\end{abstract}

Keywords Genotoxicity; Chromosomal aberrations; Momordica cymbalaria; Free radicals

\section{Introduction}

Genotoxicity is a word used in genetics that describes the possession of a substance that has a destructive effect on the genetic material of the cell (DNA, RNA) thus affecting the integrity of the cell. Genotoxins are mutagens that can cause genotoxicity leading to the damage of DNA or chromosomal material thus causing mutation (1). Mutations can be of any form; which may include duplication, insertion or deletion of genetic information. These mutations can cause a varying range of problems in the host, from a wide variety of diseases to cancer $(2,3)$.

Genotoxicity studies can be defined as various in-vitro and in-vivo tests designed to identify any substance or compounds which may induce damage to genetic material either directly or indirectly by various mechanisms. These tests should enable the identification of hazard concerning DNA damage and fixation (4). Cyclophosphamide (CP) can cause morphological changes, chromosomal abnormalities, exchange in sister chromatids mutations and unscheduled DNA synthesis (UDS) in rodent cells are in-vitro. In fungi, the drug can cause aneuploidy, mutation, recombination, gene conversion and also DNA damage. Cyclophosphamide acts as a DNA damaging agent and also as a mutagen in bacteria (5).

Chromosomes are heritable material inside the cell having unique properties that discriminate them from other cellular organelles. The number of chromosomes varies between different species but remains constant from cell to cell within same organism (6). A chromosome keeps DNA tightly bound around the histone protein. Chromosomes play an important role during cell division, which ensures that the DNA replication is accurate and distributed between newly formed cells after cell division. (7). Chromosomal alterations lead to genetic instability, which is a major cause of various genetic disorders. Consequently, chromosomal abnormality is also responsible for failure of gametogenesis, fertilization, birth defects, deformities in live-born infants and mental retardations (8).

Momordica cymbalaria (MC) is a vine of the genus momordica found in the Indian states of Andra Pradesh, Karnataka, Madhya Pradesh, Maharashtra and Tamil Nadu (9). It is a relative of bitter melon plant (M.charantia). The plant has also been named Luffa tuberosa and Momordica tuberose (Roxb.) Pharmacological studies have examined possible action of extracts of the plant in 
animal models of disease. The water extract was reported to have hypoglycemic activity in diabetic rabbits but not in normal rabbits (10). The ethanol extract was reported to protect rats from isoproterenol induced myocardial injury (11). The present study was undertaken with the objectives to explore the genotoxic effect such as chromosomal aberrations and micronucleus of the test drug Momordica cymbalaria.

\section{Materials and Methods}

\section{Collection of plant materials and plant extraction:}

Tubers of Momordica cymbalaria was procured from Gadag, Karnataka. Its identification and authentication was done by Dr. Sreenath, Department of Botany, Bangalore University, India. Preliminary phytochemical identification and extraction are done. Briefly, each $100 \mathrm{~g}$ powder was subjected to extraction with $1000 \mathrm{~mL}$ ethanol in a reflux condenser for 3 cycles of $7 \mathrm{hrs}$ each till the volume reduced to half. The extract was filtered through Whattman filter paper No.1 and evaporated to dryness. The ethanolic extract was tested for the presence of various phytochemicals. It was found a saponin in the extract was the active constituent. Further isolation and purification were achieved through flash chromatography that yielded a pure saponin fraction. This saponin fraction is used for all further experimentations (12).

\section{Genotoxicity effects}

Animals: Swiss albino mice weighing between $25-30 \mathrm{~g}$ were used for the study. Animals were housed under a standard $12 \mathrm{~h}: 12 \mathrm{~h}$ light/ dark cycle and were provided with food and water ad libitum. The experiments were performed between 10.00 and 12.hrs. All the experimental protocols were approved by Institutional Animal Ethics Committee and the study was conducted according to the CPCSEA guidelines for the use and care of experimental animals.

Drugs and chemicals: The kit for all biochemical estimations were purchased from Sigma Chemical Corp. 545 S Ewing Ave, Saint Louis, MO. The solvents and chemicals used were of analytical grade.

\section{Experimental Design}

In the present study alcoholic extract of Tubers of Momordica cymbalaria against genotoxicity was evaluated by using cyclophosphamide induced chromosomal damage in mice as a model. Thirty rats were equally divided into five groups. Animals are divided into 5 groups each group consist of 6 mice. The Group I and II were served as normal and toxic control respectively, which were administered with normal saline for 5 days. Group III and Group IV received Momordica cymbalaria $10 \mathrm{mg} / \mathrm{kg} /$ day and $50 \mathrm{mg} / \mathrm{kg} /$ day orally respectively for 5 days. Group V animals received Momordica cymbalaria $50 \mathrm{mg} / \mathrm{kg} /$ day orally in saline for 5 days. Group II to IV was administered with cyclophosphamide $50 \mathrm{mg} / \mathrm{kg} / \mathrm{IP}$
$24 \mathrm{hr}$ before the sacrifice and animals were sacrificed on the 6th day (13). Prior to this the animals were treated with colchicines $(3.5 \mathrm{mg} / \mathrm{kg} / \mathrm{IP}) 1 \frac{1}{2}$ hour before sacrifice. The femur bone was isolated and bone Marrow had been collected. Bone marrow micronucleus slides and metaphase chromosome slides were prepared and stained by the standard protocol (14). Estimation of Lipid Peroxidation and Glutathione was done using from liver homogenate

Statistical analysis: All data were expressed as mean \pm standard error means (S.E.M). The comparison of data within groups was performed by the analysis of variance (ANOVA) and followed by Tukey's test, only values with $P<0.001$ was considered as significant.

\section{Results and Discussion}

Extraction and isolation of phytoconstituents: The ethanolic extract was subjected to test for various phytoconstituents and found to contain saponins and triterpenoids while it turned out to be negative for alkaloids, glycosides, tannins and flavonoids (Table1).

Table 1. Phytoconstituents present in the ethanolic extract of Momordica Cymbalaria

\begin{tabular}{|c|c|}
\hline Phytoconstituents & $\begin{array}{c}\text { Presence/absence in } \\
\text { methanolic extract }\end{array}$ \\
\hline Alkaloids & Absent \\
\hline Glycosides & Absent \\
\hline Saponins & Present \\
\hline Triterpenoids & Present \\
\hline Flavonoids & Absent \\
\hline Tannins & Absent \\
\hline
\end{tabular}

Assessment of body weight: The diseased control group had shown effect on the body weight as it indicates the systemic toxicity and it was been compared with the test groups which had less toxicity when compared to the diseased control group. And the values have been tabulated (Table 2).

Table 2. Effect of drugs on their body weight of animals

\begin{tabular}{|c|c|c|}
\hline Treatment & Before drug $(\mathrm{gm})$ & Before sacrifice $(\mathrm{gm})$ \\
\hline Normal control & $31.33 \pm 1.096$ & $32.65 \pm 1.063$ \\
\hline Disease control & $32.00 \pm 1.072$ & $30.05 \pm 0.975$ \\
\hline Group V & $32.40 \pm 1.13$ & $31.02 \pm 1.16$ \\
\hline Group VI & $31.48 \pm 1.29$ & $31.03 \pm 1.24$ \\
\hline Group VIII & $31.83 \pm 1.012$ & $32.05 \pm 1.028$ \\
\hline
\end{tabular}

\section{Assessment of lipid peroxidation in liver homogenate}

Lipid peroxidation was increased in the diseased control group that has been treated with cyclophosphamide and it showed significant decline in the test groups. The values have been significant and are tabulated (Table 3).

\section{Glutathione assessment from liver homogenate:}

The diseased group showed toxicity by decreasing the levels of liver glutathione. And this on comparison with the test groups has showed that there was significant 
10.5530/ctbp. 2021.3s.29

Table 3: The effect of drugs on reduced glutathione and Lipidperoxidation levels of the liver induced by cyclophosphamide

\begin{tabular}{|c|c|c|}
\hline Treatment & $\begin{array}{c}\text { Glutathione lev- } \\
\text { els (mmol/min/ } \\
\text { mg/protein) }\end{array}$ & $\begin{array}{c}\text { Lipid peroxidation } \\
(\mu \mathrm{g} / \mathrm{mg} / \text { protein })\end{array}$ \\
\hline Normal control & $7.43 \pm 0.23$ & $7.95 \pm 0.2$ \\
\hline Disease control & $3.09 \pm 0.33 \# \# \#$ & $3.16 \pm 0.1 \# \# \#$ \\
\hline Group III & $5.06 \pm 0.209^{* *}$ & $4.89 \pm 0.11^{* *}$ \\
\hline Group IV & $5.84 \pm 0.12^{* * *}$ & $5.65 \pm 0.14^{* * *}$ \\
\hline Group V & $6.79 \pm 0.20$ & $6.67 \pm 0.103$ \\
\hline
\end{tabular}

increase in the glutathione in the dose dependent manner. The values have been tabulated. (Table 3 )

Values are expressed as mean \pm SEM, $(n=6){ }^{* * *} p<0.001$ compared with diseased control group. \#\#p<0.001 compared with control group.

\section{Assessment of in vivo chromosomal aberrations in mice bone marrow cells:}

The chromosomal aberrations such as gaps, chromatid breaks, exchange, rings and fragments induced by cyclophosphamide was been significantly prevented in the dose dependent manner by the test drugs and those values have been tabulated (Table 4) (Figure 1-5)

TABLE: 4 Effect of test drugs on chromosomal aberrations induced by cyclophosphamide

\begin{tabular}{|c|c|c|c|c|c|}
\hline \multicolumn{6}{|c|}{ Types of chromosomal aberrations } \\
\hline Treatment & Breaks & Elongation & Gaps & $\begin{array}{l}\text { Multiple } \\
\text { aberra- } \\
\text { tions }\end{array}$ & $\begin{array}{l}\text { Total cells of } \\
\text { aberrations }\end{array}$ \\
\hline $\begin{array}{l}\text { Normal } \\
\text { control }\end{array}$ & $\begin{array}{l}0.66 \pm \\
0.12\end{array}$ & $\begin{array}{l}0.33 \pm \\
1.23\end{array}$ & $\begin{array}{l}0.33 \pm \\
0.23\end{array}$ & 0.5000 & $0.33 \pm 0.26$ \\
\hline $\begin{array}{l}\text { Dis- } \\
\text { ease } \\
\text { control }\end{array}$ & $\begin{array}{l}12.00 \\
\pm 0.12 \\
\# \# \#\end{array}$ & $\begin{array}{l}11.83 \pm \\
0.45 \# \# \#\end{array}$ & $\begin{array}{l}14.33 \pm \\
0.45 \# \# \#\end{array}$ & $\begin{array}{l}14.33 \pm \\
0.88 \# \# \#\end{array}$ & $\begin{array}{l}13.12 \pm \\
0.26 \# \# \#\end{array}$ \\
\hline $\begin{array}{l}\text { Group } \\
\text { III }\end{array}$ & $\begin{array}{l}9.83 \pm \\
0.67^{* *}\end{array}$ & $\begin{array}{l}8.50 \pm \\
0.87^{* *}\end{array}$ & $\begin{array}{l}8.16 \pm \\
0.65^{\star *}\end{array}$ & $\begin{array}{l}9.50 \pm \\
0.78^{* *}\end{array}$ & $\begin{array}{l}4.00 \\
\pm 0.24^{* *}\end{array}$ \\
\hline $\begin{array}{l}\text { Group } \\
\text { IV }\end{array}$ & $\begin{array}{l}5.83 \pm \\
0.45^{\star * *}\end{array}$ & $\begin{array}{l}4.83 \pm \\
0.12\end{array}$ & $\begin{array}{l}0.33 \pm \\
0.13\end{array}$ & $\begin{array}{l}4.83 \pm \\
0.98\end{array}$ & $4.74 \pm 0.23$ \\
\hline $\begin{array}{l}\text { Group } \\
\text { V }\end{array}$ & \begin{tabular}{|l|}
$0.50 \pm$ \\
0.12
\end{tabular} & $\begin{array}{l}0.33 \pm \\
0.13\end{array}$ & 0.000 & $\begin{array}{l}0.16 \pm \\
-.67\end{array}$ & $0.25 \pm 0.12$ \\
\hline
\end{tabular}

Values are expressed as mean \pm SEM, $(n=6){ }^{* * *} p<0.001,{ }^{* *} p<0.05$, compared with diseased control group. \#\#p<0.001, \#\#p<0.05, with control group

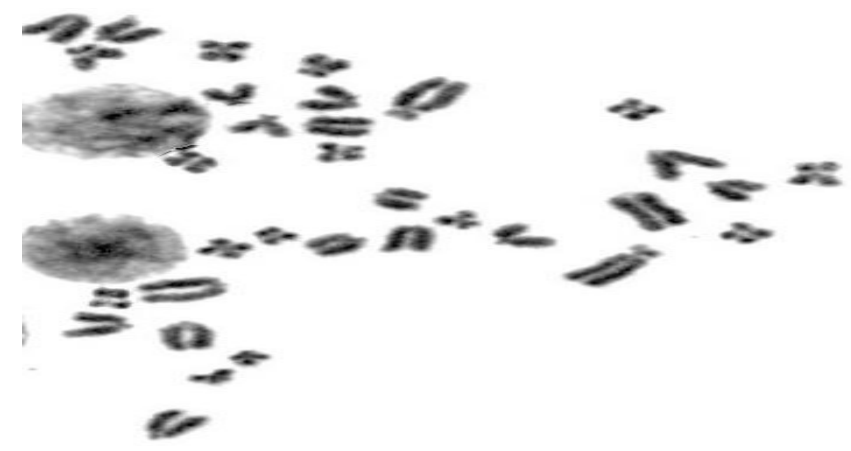

Figure 1: Control Group

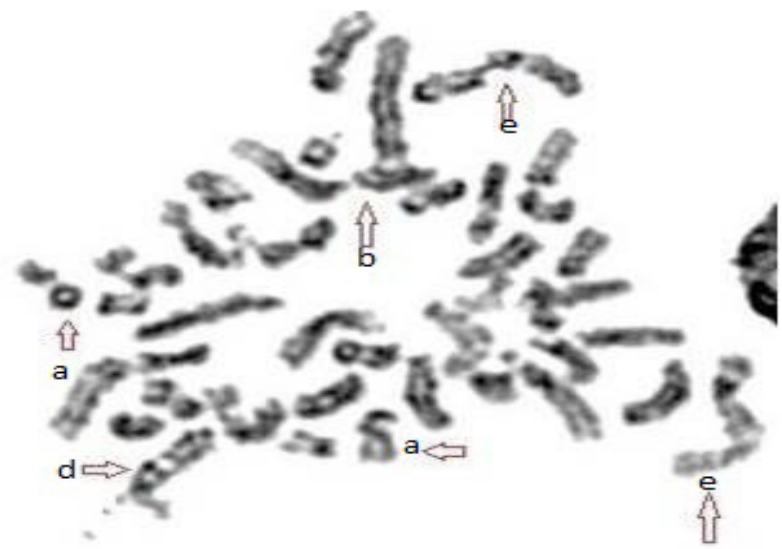

Figure 2: Diseased control group

(a- ring, b- gap, d- elongation, e-fragments)

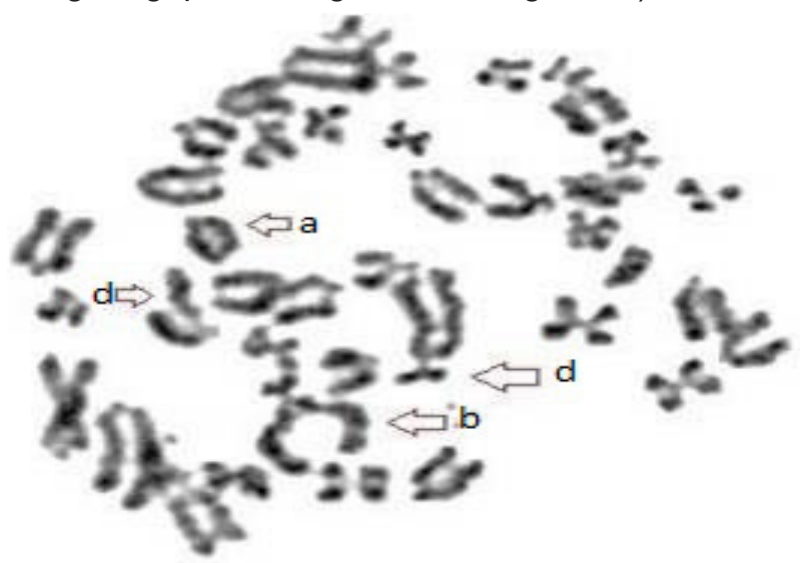

Figure $3:$ MC 10mg/kg = CP 50mg.

(a- ring, b- gap, d- elongation, )

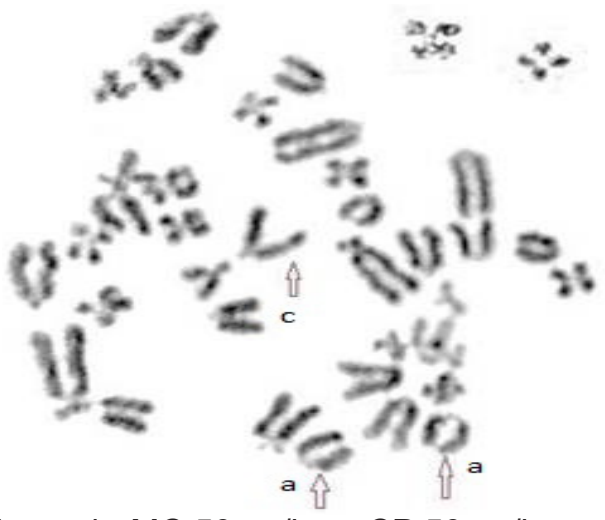

Figure $4: \mathrm{MC} 50 \mathrm{mg} / \mathrm{kg}=\mathrm{CP} 50 \mathrm{mg} / \mathrm{kg}$ (a- ring, c- break, )

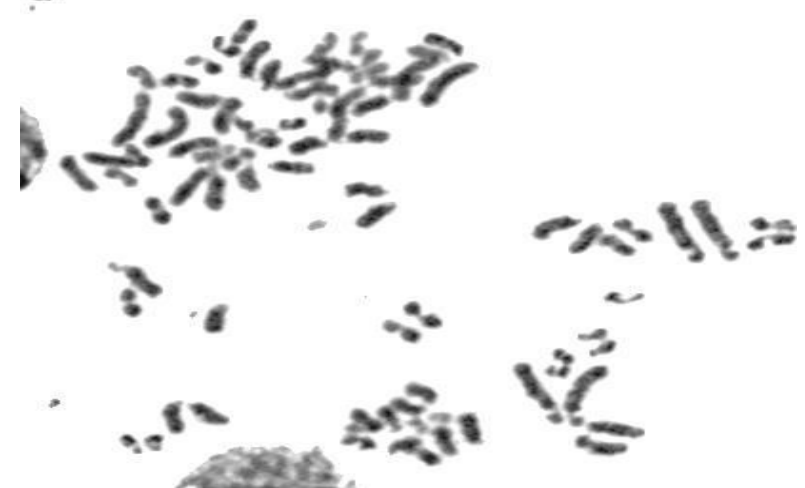

Figure 5: MC 50mg/kg 
Table 5: Effect of drugs on the bone marrow cells

\begin{tabular}{|c|c|c|c|c|}
\hline $\begin{array}{c}\text { Treat- } \\
\text { ment }\end{array}$ & $\begin{array}{c}\text { Normo- } \\
\text { chromat- } \\
\text { ic eryth- } \\
\text { rocytes } \\
(\%)\end{array}$ & $\begin{array}{c}\text { Polychro- } \\
\text { matic } \\
\text { erythro- } \\
\text { cytes }(\%)\end{array}$ & p/n ratio & $\begin{array}{c}\% \text { micronu- } \\
\text { clei }\end{array}$ \\
\hline Normal & $320 \pm$ & $560 \pm$ & $0.63 \pm$ & $15.1 \pm$ \\
control & 10.8 & 9.23 & 0.23 & 0.2 \\
\hline Disease & $350 \pm$ & $140 \pm$ & $0.28 \pm$ & $54 \pm 0.1$ \\
control & $15.09 \# \#$ & $14.33 \# \# \#$ & $0.33 \# \# \#$ & $\# \#$ \\
\hline Group III & $430 \pm$ & $264 \pm$ & $0.38 \pm$ & $421 \pm$ \\
& 6.12 & $4.56 * *$ & $0.2 * *$ & $0.11^{* *}$ \\
\hline Group IV & $374 \pm$ & $441 \pm$ & $0.54 \pm$ & $34.4 \pm$ \\
$7.14 * * *$ & $6.45^{* * *}$ & $0.12^{* * *}$ & $0.14 * *$ \\
\hline Group V & $320 \pm$ & $510 \pm$ & $0.61 \pm$ & $22.4 \pm$ \\
& 6.23 & 6.54 & 0.20 & 0.13 \\
\hline
\end{tabular}

Values are expressed as mean \pm SEM, $(n=6)$ : ${ }^{* * *} p<0.001,{ }^{* *} p<0.05$, compared with diseased control group. \#\#\#<0.001, \#\#p<0.05, compared with control group.

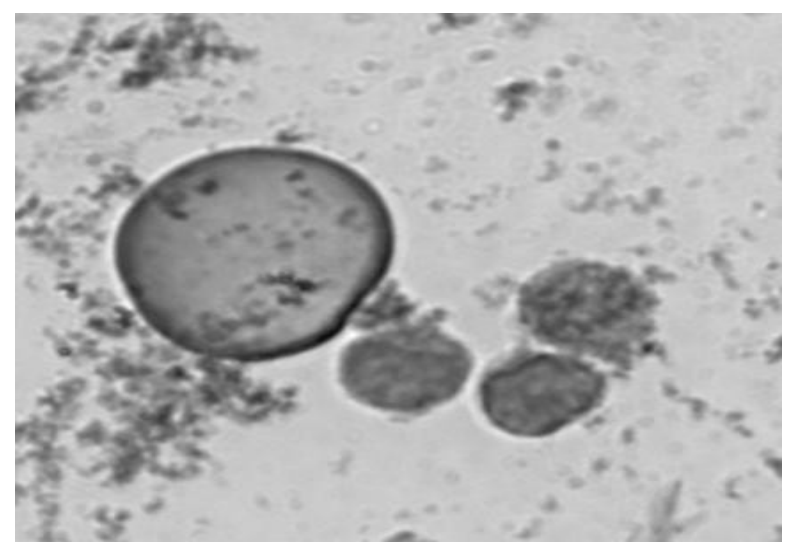

Figure 6: Control group

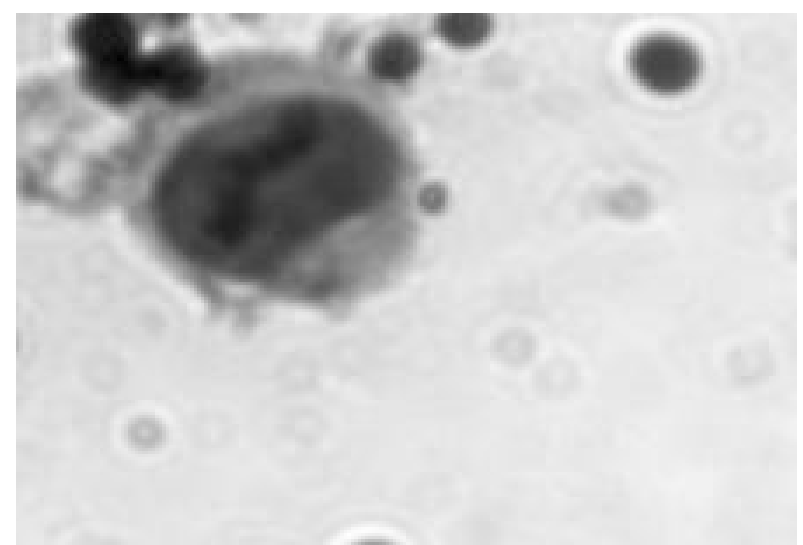

Figure7: Disease Control group

\section{Invivo micro nuclei assay in mice bone marrow cells:}

The significant increase in formation of polychromato erythrocytes that was observed in diseased control group which received cyclophosphamide of $50 \mathrm{mg} / \mathrm{kg}$ body weight. While the test groups showed decrease in the polychromato erythrocytes. And the mitotic index was found out which has been tabulated (Table 5) (Figure 6-10).

Through the ages, plants have always offered huge prospects toward the betterment of

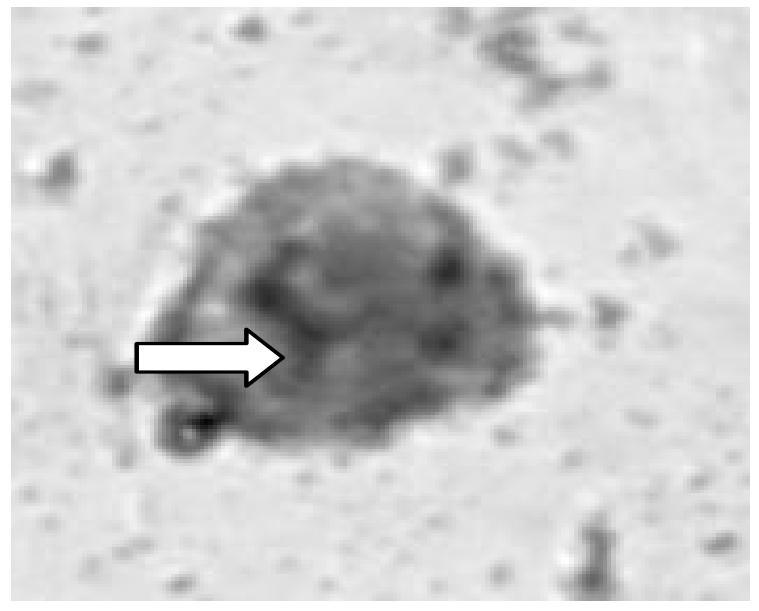

Figure 8: MC 10mg/kg + CP 50mg/kg

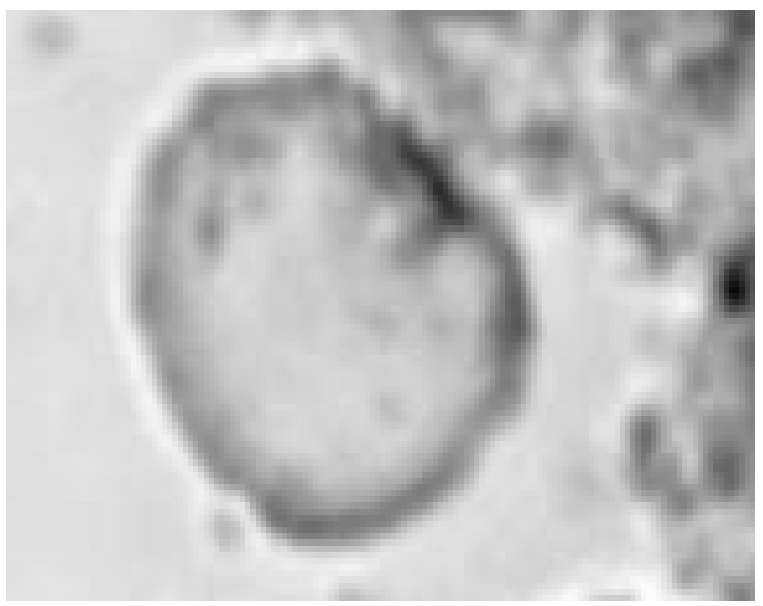

Figure 9: $\mathrm{MC} 50 \mathrm{mg} / \mathrm{kg}+\mathrm{CP} 50 \mathrm{mg} / \mathrm{kg}$

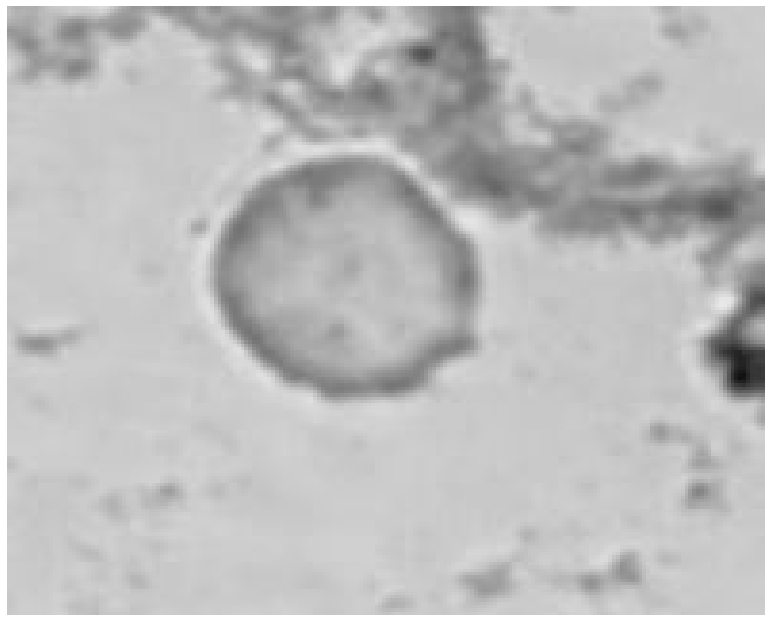

Figure 10: MC 50mg/kg

human health either by ameliorating disease conditions or enhancing normal physiological activity. Every drug possesses toxic effects but a valuable pharmacologically active compound should have an acceptable balance between therapeutic effects and toxic /untoward effects. To ensure the safety and efficacy of natural products, a battery of genotoxic and/ or mutagenicity assays are required to be performed to screen the toxicity mechanism (15). Although an antimutagen is not necessarily an anti-carcinogen, yet it 
is an indication of a possible anticarcinogen. It was reported earlier that several anti-tumour compounds act through the anti-mutagenic mechanism. Hence searching for the antimutagenic compounds represents a rapidly expanding field of cancer research plants having antimutagenic potential can also be used as an adjuvant with the chemotherapeutic drugs to reduce the side effects associated with the chemotherapy (16). Cyclophosphamide is a standard drug used for various types of cancer as well as for the immunosuppressive therapy for rheumatoid arthritis, systemic lupus erythematosus etc. Cyclophosphamide is also used as a standard drug to induce micronucleus and chromosomal aberration in the cancer research experiments (17). Reduction of bodyweight with cyclophosphamide was observed at the beginning of the study with the survival rate of $98 \%$ to the end of the study. Group V have shown an increase in their weight towards the end of treatment. Even though there is a reduction in body weight when test drug is given with cyclophosphamide, when the test drug was administered results have shown an increase in body weight before sacrifice which may be due to the stimulatory effect of Momordica cymbalaria at high doses. (Table 2) Glutathione (GSH) is the most abundant low molecular weight thiol compound synthesized in cells. GSH plays critical roles in protecting cells from oxidative damage and the toxicity of xenobiotic electrophiles, and maintaining redox homeostasis. Here, the functions and GSH and the sources of oxidants and electrophiles, the elimination of oxidants by reduction and electrophiles by conjugation with GSH (18). Cyclophosphamide or one of its toxic metabolites, acrolein, may potentiate oxygen toxicity by depressing antioxidant defence mechanisms. Cyclophosphamide, but not acrolein, depresses antioxidant defence mechanisms, which may be responsible for increased mortality from $\mathrm{O} 2$ toxicity in cyclophosphamide-treated animals (19). The levels of glutathione in liver homogenate showed a significant decrease in the disease group with comparison to the test groups. Momordica cymbalaria alone treated groups showed a significant increase in the glutathione levels in a dose dependent manner (Table 3).

Lipid peroxidation is the process in which free radicals attack unsaturated fatty acids in a lipid membrane. The radical extracts a hydrogen atom from the lipid leaving behind a lipid radical and setting off an oxygen-mediated chain reaction that leaves the membrane riddled with lipid hydroperoxides (nonradical intermediates of lipid peroxidation) (20) . Lipid peroxidation has increase therapeutic index of the drug by way of reducing toxicity that may be mediated through free radical mechanisms (21).

A chromosome aberration, or mutation is a missing or extra, or irregular portion of chromosomal DNA. It can be from an atypical number of chromosomes or a structural abnormality in one or more chromosomes. Different types of aberrations were observed in the study as elongation, gap, ring, chromatic breaks etc. Diseased group has shown more aberrations like elongation, gap etc more than drug treated groups indicating the toxicity of cyclophosphamide and groups $\mathrm{V}$ has shown decreased cells of aberrations indicating that Momordica cymbalaria has no genotoxic effect.

Cytotoxicity of cyclophosphamide was evidenced in the present study in the form of reduction of MI and $\mathrm{P} / \mathrm{N}$ ratio. Momordica cymbalaria showed an increase in $\mathrm{Ml}$ and $\mathrm{P} / \mathrm{N}$ ratio comparatively but higher doses of Momordica cymbalaria is having a significant increase in the mitotic index and $\mathrm{P} / \mathrm{N}$ ratio in micronucleus test and chromosomal aberration study at a certain instance which may be due to the stimulatory action of the drugs on cell division. Animals receiving only $\mathrm{MC}$ (group V) resulted in an increase in the polychromatic erythrocytes in their cells. These groups didn't show any statistically significant difference when compared to the control group. Cyclophosphamide treated group (group II) have shown an increased in the number of micronucleated polychromatic erythrocytes but this effect of cyclophosphamide was significantly reduced in a dose-dependent manner by pre-treatment with Momordica cymbalaria (group III and IV ).

\section{Conclusion}

To draw the conclusio $\mathrm{n}$ out of the research performed, it is observed that Momordica cymbalaria showed dose dependent protective effect against animals treated with cyclophosphamide which is known inducer of genotoxicity. It can be noticed that the CP metabolites, generation of ROS and free radicals may be the major reason for the toxicity produced which was observed by the levels of GSH, lipid peroxidation, formation of micronuclei and chromosomal aberrations. But it was observed that there was significant dose dependent protection against the toxicity induced by $\mathrm{CP}$ in the animals pre-treated with Momordica cymbalaria. In the animals treated with Momordica cymbalaria alone there was no toxicity detected on comparing with the control.

A clear negative effect on the induction of chromosomal aberrations and increased mitotic index by Momordica cymbalaria was found. The results of the present study clearly showed that the drugs had an antimutagenic and anticlastogenic potential against the mutagenic activity of cyclophosphamide in mice. However, further studies are needed in other test systems so that in future this drugs can be used in reducing the occurrence of cancers or even as a coadjuvant to chemotherapy to reduce its side effects

\section{References}

1. De Flora, S., and Izzotti, A. (2007). Mutagenesis and cardiovascular diseases: molecular mechanisms, 
risk factors, and protective factors. Mutation Research/Fundamental andMolecular Mechanisms of Mutagenesis, 621: 5-17.

2. Mohamed, S.A., Sabita, U., Rajendra, S. and Raman, D. (2017). Genotoxicity: mechanisms, testing guidelines and methods. Glob. J. Pharm. Pharm. Sci,1: 1-6.

3. Savage, J.R. (1976) Classification and relationships of induced chromosomal structural changes. Journal of medical genetics, 13(2): 103-122.

4. Mei, N., Guo, L., Fu, P.P., Fuscoe, J.C., Luan, Y. and Chen, T. (2010). Metabolism, genotoxicity, and carcinogenicity of comfrey. Journal of Toxicology and Environmental Health, Part B. 13(7-8): 509-526.

5. Sistigu, A., Viaud, S., Chaput, N., Bracci, L., Proietti, E. and Zitvogel, L. (2011 ).Immunomodulatory effects of cyclophosphamide and implementations for vaccine design. Seminars in immunopathology, 33: 369-383.

6. Branda, R.F., Brooks, E.M., Chen, Z., Naud, S.J. and Nicklas, J.A. (2002). Dietary modulation of mitochondrial DNA deletions and copy number after chemotherapy in rats. Mutation Research/ Fundamental and Molecular Mechanisms of Mutagenesis, 501(1- 2): 29-36.

7. Ferguson. and Smith, M.A. (1987). Essential medical genetics. Blackwell Scientific.

8. Cremer, C., Münkel, C., Granzow, M., Jauch, A., Dietzel, S., Eils, R., Guan, X.Y., Meltzer,P.S., Trent, J.M., Langowski, J. and Cremer, T. (1996). Nuclear architecture and the induction of chromosomal aberrations. Mutation Research/Reviews in Genetic Toxicology, 366(2): 97-116.

9. Patel, D.K., Patel, K. and Tahilyani, V. (2012). Barbaloin: a concise report of its pharmacological and analytical aspects. Asian Pacific journal of tropical biomedicine, 2(10): 835- 838.

10. Parvathi, S. and Kumar, V.J. (2002). Studies on chemical composition and utilization of the wild edible vegetable athalakkai (Momordica tuberosa). Plant Foods for Human Nutrition, 57(3-4): 215222.

11. Pandey, A. and Prakash, K.A. (2013). Note on Debatable Taxonomic Identity of Luffa tuberosa Roxb.(Cucurbitaceae): A Potential Wild Edible Vegetable in India. Indian Journal ofPlant Genetic Resources,26(2): 124-127.

12. Deore, S.L. and Khadabadi, S.S. (2010). Isolation and characterization of phytoconstituents from Chlorophytum borivilianum. Pharmacognosy research, 2(6): 343.

13. Daripelli, S.V., Vishwanath, J., Swamy, B.M. and Reddy, P. (2011). Antidepressant activity of hydroalcoholic extract of fruits of momordica cymbalaria hook in animal models. Journal of Chemical and Pharmaceutical sciences, 4(4): 158-162.

14. Fahim, F.A., Esmat, A.Y., Mady, E.A. and Amin, M.A. (1997). Serum LDH and ALP isozyme activities in mice bearing solid Ehrlich carcinoma and/or treated with the maximum tolerated dose (MTD) of aloin. Disease markers, 13(3): 183-193.

15. Wongpa, S., Himakoun, L., Soontornchai, S. and Temcharoen, P. (2007). Antimutagenic effects of piperine on cyclophosphamideinduced chromosome aberrations in rat bone marrow cells. Asian Pacific Journal of Cancer Prevention,8(4): 623-627.

16. Mohamed, H.M. and Aly, M.S. (2018). Evaluation of genotoxicity of Euphorbia triaculeata

Forssk. extract on mice bone marrow cells in vivo. Toxicology reports, 5: 625-631.

17. Burke, R.W., Diamondstone, B.I., Velapoldi, R.A. and Menis, O. (1974). Mechanisms of the Liebermann-Burchard and Zak color reactions for cholesterol. Clinical chemistry, 20 (7): 794-801.

18. Tripathi, D.N. and Jena, G.B. (2008). Astaxanthin inhibits cytotoxic and genotoxic effects of cyclophosphamide in mice germ cells. Toxicology, 248(2-3): 96-103.

19. Gaucher, C., Boudier, A., Bonetti, J., Clarot, I., Leroy, P. and Parent, M. (2018). Glutathione: antioxidant properties dedicated to nanotechnologies. Antioxidants, 7(5):62

20. Patel, J.M. and Block, E.R. (1985). Cyclophosphamide-induced depression of the antioxidant defence mechanisms of the lung. Experimental lung research, 8(2-3): 153-165.

21. Ray, S., Pandit, B., Das, S. and Chakraborty, S. (2011). Cyclophosphamide-induced lipidperoxidation and changes in cholesterol content. Protective role of reduced glutathione, 7(4): $255-267$. 